\title{
Phytotoxicity of a Culture Filtrate Produced by Stemphylium solani of Cotton
}

\author{
Y. R. Mehta and R. L. Brogin, Instituto Agronômico do Paraná-IAPAR, Caixa Postal 481, CEP-8600-970, Lon- \\ drina, PR., Brazil
}

\begin{abstract}
Mehta, Y. R., and Brogin, R. L. 2000. Phytotoxicity of a culture filtrate produced by Stemphylium solani of cotton. Plant Dis. 84:838-842.
\end{abstract}

Stemphylium solani, which causes a new leaf blight of cotton, was suspected of producing a phytotoxin. Studies were conducted to examine the relationship between the reaction of different cotton cultivars and of some unrelated host species to the pathogen and its toxin-containing culture filtrates. Seven single spore isolates of $S$. solani from cotton and their toxin-containing culture filtrates were used for leaf and root bioassays. An isolate of $S$. solani from tomato was also used for comparison. The phytotoxic effect was isolate dependent. Culture filtrates of five isolates killed 40 to $60 \%$ of the cotton seedlings when incubated for 4 days at $10^{-1}$ dilution. At $10^{-2}$ dilution, the culture filtrates of most of the isolates affected the development of the root system but failed to kill any seedling. The phytotoxic effect of the culture filtrate was not degraded by autoclaving. A high correlation coefficient between the percentage of the leaf area infected (LAI) by S. solani and the percentage of the necrotic leaf area (LAN) by the culture filtrate was observed when one of the aggressive isolates and its culture filtrate were tested against adult plants of 38 cotton cultivars $(r=0.86)$. Cultivars CNPA T-1180-23, CNPA-PRECOCE 2, PR 94-215, and PR 94-82 demonstrated resistance to the pathogen as well as insensitivity or moderate sensitivity to its toxin. Cultivars showing intermediate reaction to the pathogen also showed intermediate reaction to its culture filtrate. Similarly, the highly susceptible cultivars Paraná 3, PR 93-129, and PR 94-216 also were highly sensitive to the culture filtrate. Of the 18 plant species belonging to 18 genera, eight were susceptible to the pathogen. With two exceptions, susceptible hosts were also sensitive to the culture filtrate, whereas nonsusceptible hosts were insensitive. A component of the culture filtrate was regarded as a pathogenicity factor.
An unusual leaf blight of cotton (Gossypium hirsutum) occurred in the state of Paraná, Brazil, during 1994 to 1996, causing up to $100 \%$ yield loss in some commercial fields planted to the cultivar Paraná 3 (3). The severe outbreak of the disease was correlated with the rapid expansion of the new cotton cultivar Paraná 3 to over $65 \%$ of the cotton growing area.

The Stemphylium leaf blight symptoms previously described (3) are characterized as small, circular to irregular, dark brown to black lesions, varying between 2 and 5 $\mathrm{mm}$ and becoming reddish brown with age. In the pathogenicity tests conducted with artificial inoculations, some unusual symptoms were observed along with the typical Stemphylium leaf blight symptoms. Light brown to off-white blotches with no definite margin developed and reached up to $2.5 \mathrm{~cm}$ in diameter. Such lesions were suspected to be due to a phytotoxin produced by $S$. solani. In varietal screening for disease resistance, it is worthwhile to know whether or not the phytotoxin has host- or cultivarspecific activity.

Corresponding author: Y. R. Mehta

E-mail: yrmehta@pr.gov.br

Accepted for publication 27 March 2000.

Publication no. D-2000-0522-01R

(C) 2000 The American Phytopathological Society
The first report of a host-selective phytotoxin produced by Alternaria kikuchiana, causal fungus of the black spot disease of Japanese pear (Pyrus pyrifolia), appeared in 1933 (5). Detailed studies were reported by several workers regarding the host-selective phytotoxins produced by $A$. kikuchiana, A. alternata, Cochliobolus carbonum, C. victoriae, and Periconia circinata (8). In recent years, several other pathogens have been reported to produce host-specific phytotoxins $(2,4,5,8)$. In the present study, attempts were made to determine whether a phytotoxin was involved in the disease syndrome of Stemphylium leaf blight of cotton.

\section{MATERIALS AND METHODS}

Production of culture filtrate. Seven arbitrarily selected single-spore isolates of
S. solani (culture collection no. 11653, 11654, 11660, 11679, 11683, 11685, 11687), obtained from different locations and cotton cultivars in the state of Paraná, were cultured on potato dextrose agar (PDA) medium for 7 days and used as initial inoculum. An isolate of $S$. solani from tomato (T-1953) also was used for comparison (Table 1). Inoculum disks ( 0.5 $\mathrm{cm}$ diameter) were cut with a cork borer and transferred to 250-ml Erlenmeyer flasks containing $100 \mathrm{ml}$ of potato dextrose broth. The flasks were incubated in still conditions for 15 days at $24^{\circ} \mathrm{C}$ with $16 / 8 \mathrm{~h}$ light and dark period. The broth was filtered through Whatman filter paper no. 1, filtered through a sterile $0.45-\mu \mathrm{m}$ Metrical filter, adjusted to $\mathrm{pH} 6.8$ with $5 \mathrm{~N} \mathrm{KOH}$, and stored overnight at $5^{\circ} \mathrm{C}$. Precipitates were removed by centrifugation at 4,000 rpm for $10 \mathrm{~min}$, and the supernatant was autoclaved at $120^{\circ} \mathrm{C}$ for $20 \mathrm{~min}$.

Cotton root bioassay. Eight singlespore isolates of $S$. solani and their culture filtrates were used in a cotton root bioassay. Culture filtrates from four isolates were tested in experiment 1 and from the other four in experiment 2. Cotton seeds of cultivar Paraná 3 were grown for 3 days in moist paper towels in the incubator at $24^{\circ} \mathrm{C}$. Healthy and uniform seedlings were selected, root length was measured, and each seedling was grown in a $10-\mathrm{ml}$ test tube $(10 \times 1 \mathrm{~cm})$ with autoclaved fungal culture filtrates in three different dilutions $\left(10^{-1}, 10^{-2}\right.$, and $\left.10^{-3}\right)$. Autoclaved potato dextrose broth at 1:10 dilution was maintained as a control. Roots were suspended in the test tube while the cotyledons were kept exposed to the air. Fifteen seedlings per dilution were used and were incubated at $21^{\circ} \mathrm{C}$. Root length was measured 4 days after incubation. Percentage of dead seedlings and the percent increase in root length were recorded. The data were assessed by analysis of variance for a randomized complete block design. Means
Table 1. Origin of isolates of Stemphylium solani from cotton used for culture filtrate study

\begin{tabular}{lccc}
\hline & & \multicolumn{2}{c}{ Origin } \\
\cline { 3 - 4 } Isolate no. & Isolate code & Cultivar & Location \\
\hline 1 & 11653 & 0 C92-183 & Maringa \\
2 & T-1953 & Unknown & Piracicaba \\
3 & 11654 & PR-122 & Maringa \\
4 & 11660 & Unknown & Londrina \\
5 & 11679 & PR92-122 & Goioeré \\
6 & 11683 & Unknown & Banderantes d'Oeste \\
7 & 11685 & Unknown & Janinópolis \\
8 & 11687 & IAPAR-71 & Jesuíta \\
\hline
\end{tabular}

${ }^{\mathrm{z}}$ Isolate from tomato. 
were compared by Duncan's multiple range test. The assay endpoint was determined after 4 days as that maximum dilution at which the percent increase in root length was statistically lower than that of the control.

A concentrated culture filtrate preparation from isolate 11687 also was bioassayed. For this purpose, the culture filtrate was concentrated 10 -fold under partial vacuum at $45^{\circ} \mathrm{C}$, an equal amount of methanol was added, and the mixture was stored overnight at $5^{\circ} \mathrm{C}$. The resulting precipitate was filtered off through Whatman no. 1 paper, and the filtrate was concentrated under partial vacuum to the original volume and until all the methanol was evaporated.

Leaf bioassay. Cotyledons of 15-dayold seedlings of cotton cv. Paraná 3 were infiltrated individually with the autoclaved culture filtrates of all the isolates at $10^{-1}$ dilution using a soft paint brush (3). Plants were incubated in a dew chamber for a period of $48 \mathrm{~h}$ at $21^{\circ} \mathrm{C}$ and later transferred to a glasshouse, where the relative humidity ranged from 45 to $60 \%$ during the day and about $85 \%$ during the night. Day and night temperature means during the test period were 24 and $19^{\circ} \mathrm{C}$, respectively. Seedlings were assessed 4 days later for symptoms. The percent necrotic area of the eight cotyledons was assessed by visual observation (0 to 99\%). Control seedlings infiltrated with autoclaved potato dextrose broth at 1:10 dilution were maintained.

Host specificity. To determine whether the culture filtrate was phytotoxic to other hosts, leaves of 15-day-old seedlings were examined in the leaf bioassay. The hosts included barley (Hordeum vulgare) cv. BR 2, beans (Phaseolus vulgaris) cv. Carioca, coffee (Coffea arabica) cv. Mundo Novo, cotton cv. Paraná 3, crotalaria (Crotalaria anageroides, C. mucronata, C. paulinea, $C$. retusa, and $C$. spectabilis), faba beans (Vicia faba), lupins (Lupinus albus) cv. Floresta, maize (Zea mays) hybrid XL-321, mucuna (Styzolobium atterrimum), oats (Avena sativa) cv. IAC 7, peas (Pisum sativum) cv. IAPAR 58, potato (Solanum tuberosum) cv. Achat, rice (Oryza sativa) cv. Agulhinha, rye (Secale cereale) cv. BR 1, soybean (Glycine max) cv. EMBRAPA 4, tomato (Lycopersicon esculentum) cv. Agricica, triticale (X. Triticosecale) cv. Arapoti, and wheat (Triticum aestivum) cv. Mirim. Each host was inoculated with a mixture of seven aggressive isolates of $S$. solani (culture collection no. 11653, 11654, $11660,11679,11683,11685,11687)$ and were infiltrated with a mixture of their crude autoclaved filtrates (Table 1).

Although spore counts were not made, apparently a higher sporulation was obtained within 10 to 12 days in PDA containing $50 \mathrm{~g}$ of macerated young green leaves of $S$. atterrimum and an equal amount of macerated young green leaves of Lupinus angustifolius per 1,000 $\mathrm{ml}$. Inoculum was prepared as described earlier
(3). Equal amounts of inoculum per isolate, i.e., fungal colonies grown under identical conditions and on an equal number of culture plates per isolate were used. The spore concentration in the inoculum mixture was 9,500 spores per ml. Five young leaves per plant species (one leaf per plant) were inoculated with the pathogen, and the other five young leaves of the same host were infiltrated with the phytotoxin preparation of the same isolates using a soft paint brush (3). Noninoculated control plants were infiltrated with potato dextrose broth and distilled water. After $48 \mathrm{~h}$ incubation in a dew chamber set at $21^{\circ} \mathrm{C}$ and nearsaturated humidity, the inoculated plants were transferred to the glasshouse. In the glasshouse, the relative humidity ranged from 60 to $75 \%$ during the day and about $90 \%$ at night, and day and night temperature means during the test period were 23 and $19^{\circ} \mathrm{C}$, respectively. At 9 days after inoculation-infiltration, three leaves showing the highest leaf area infected (LAI) by the pathogen (as estimated by visual observation) and another three showing the highest necrotic leaf area (LAN) by the culture filtrate per plant species were detached from the plants, and the areas of the visible LAI/LAN were traced on thin transparent plastic sheets with black ink and were assessed using a portable area meter, LI-3000 (LAMDA Instruments Corp., Lincoln, NE).

Table 2. Effect of crude autoclaved filtrates obtained from 15-day-old cultures of Stemphylium solani on the development of cotton seedlings of cv. Paraná 3 (experiment 1)

\begin{tabular}{|c|c|c|c|c|c|}
\hline \multirow{3}{*}{$\begin{array}{l}\text { Isolate of } \\
\text { S. solani }\end{array}$} & \multirow{3}{*}{$\begin{array}{l}\% \text { necrotic area } \\
\text { of cotyledons }\end{array}$} & \multicolumn{3}{|c|}{$\begin{array}{c}\% \text { increase in root length of seedlings } \\
4 \text { days after incubation }\end{array}$} & \multirow{3}{*}{$\begin{array}{c}\% \text { dead } \\
\text { seedlings }\end{array}$} \\
\hline & & \multirow{2}{*}{$\begin{array}{l}\text { Potato dextrose } \\
\text { broth }\end{array}$} & \multicolumn{2}{|c|}{ Dilution of fungal filtrate } & \\
\hline & & & 01:10 & $1: 100$ & \\
\hline$\overline{\text { Control }^{z}}$ & 0 & $42.0 \mathrm{a}$ & & & 0 \\
\hline 11653 & 80 & & $21.0 \mathrm{~b}$ & $44.4 \mathrm{a}$ & 40 \\
\hline 11654 & 60 & & $19.3 \mathrm{~b}$ & $49.8 \mathrm{a}$ & 27 \\
\hline 11683 & 100 & & $18.7 \mathrm{~b}$ & $26.0 \mathrm{~b}$ & 47 \\
\hline T-1953 & 10 & & $3.4 \mathrm{c}$ & $22.3 \mathrm{~b}$ & 0 \\
\hline
\end{tabular}

${ }^{w}$ Average of 15 seedlings. Means followed by the same letter did not differ statistically (Duncan $5 \%)$.

${ }^{x}$ Average of eight cotyledons, 4 days after infiltration with culture filtrate at 1:10 dilution.

${ }^{y}$ Four days after incubation in culture filtrate at 1:10 dilution.

${ }^{\mathrm{z}}$ Infiltrated with autoclaved potato dextrose broth at 1:10 dilution.

Table 3. Effect of crude autoclaved filtrates obtained from 15-day-old cultures of Stemphylium solani on the development of cotton seedlings of cv. Paraná 3 (experiment 2)

\begin{tabular}{|c|c|c|c|c|c|}
\hline \multirow{3}{*}{$\begin{array}{l}\text { Isolate of } \\
\text { S. solani } \\
\end{array}$} & \multirow{3}{*}{$\begin{array}{l}\text { \% necrotic area } \\
\text { of cotyledons }\end{array}$} & \multicolumn{3}{|c|}{$\begin{array}{c}\% \text { increase in root length of seedlings } \\
\mathbf{4} \text { days after incubation }{ }^{w} \\
\end{array}$} & \multirow{3}{*}{$\begin{array}{r}\% \text { dead } \\
\text { seedlings }\end{array}$} \\
\hline & & \multirow{2}{*}{$\begin{array}{l}\text { Potato dextrose } \\
\text { broth }\end{array}$} & \multicolumn{2}{|c|}{ Dilution of fungal filtrate } & \\
\hline & & & 01:10 & $1: 100$ & \\
\hline Control $^{\mathrm{z}}$ & 0 & $42.3 \mathrm{a}$ & & & 0 \\
\hline 11660 & 40 & & $22.7 \mathrm{~b}$ & $39.9 \mathrm{a}$ & 40 \\
\hline 11685 & 40 & & $18.7 \mathrm{~b}$ & $41.4 \mathrm{a}$ & 27 \\
\hline 11679 & 40 & & $17.6 \mathrm{~b}$ & $40.2 \mathrm{a}$ & 33 \\
\hline 11687 & 95 & & $7.0 \mathrm{c}$ & $34.5 \mathrm{a}$ & 60 \\
\hline
\end{tabular}

${ }^{\mathrm{w}}$ Average of 15 seedlings. Means followed by the same letter did not differ statistically (Duncan $5 \%)$.

${ }^{\mathrm{x}}$ Average of eight cotyledons, 4 days after infiltration with culture filtrate at 1:10 dilution.

y Four days after incubation in culture filtrate at 1:10 dilution.

${ }^{\mathrm{z}}$ Infiltrated with autoclaved potato dextrose broth at 1:10 dilution. 
coefficient was determined with the computer program Cricket Graph for Macintosh.

\section{RESULTS}

Phytotoxicity of the culture filtrate. All eight cotton isolates of $S$. solani produced a culture filtrate which was phytotoxic to cotton leaves and roots but differed greatly in amounts of toxin production (Tables 2 and 3). Crude culture filtrates at $10^{-1}$ dilution, either autoclaved or not, gave similar results, and hence only results of autoclaved culture filtrate at $10^{-1}$ and $10^{-2}$ dilutions are presented.

Bioassays. The presence of a phytotoxic compound of the culture filtrate was detected by infiltrating leaves of cotton seedlings of cv. Paraná 3 with the culture filtrate. The first toxic symptoms were noticeable within $24 \mathrm{~h}$ after infiltration as sunken spots of irregular sizes. Later, welldeveloped symptoms were easily noticeable within 4 days after infiltration, similar to the time required for the expression of symptoms when plants were inoculated with $S$. solani. The phytotoxin produced by $S$. solani was capable of eliciting the disease symptoms on leaves as observed under field conditions, and no clear-cut distinction could be made between leaf symptoms produced by the culture filtrates and by the pathogen itself (Fig. 1).

Culture filtrates of five isolates killed 40 to $60 \%$ of the cotton seedlings when incubated for 4 days at $10^{-1}$ dilution. At $10^{-2}$ dilution, culture filtrates of most of the isolates affected the development of the root system but failed to kill any seedlings. Concentrated toxin prepared under partial vacuum was effective and killed $100 \%$ of the seedlings at $10^{-1}$ dilution in the root bioassay but not at $10^{-2}$ dilution. Although a slight reduction in root length caused by the culture medium itself was noticed as compared with the distilled water, control plants infiltrated either with culture medium or with distilled water did not show any mortality.

Filtrates from all the isolates gave at least $50 \%$ inhibition of root growth at $10^{-1}$ dilution (Tables 2 and 3). The healthy cotton seedlings grown in liquid medium or distilled water as control developed clearly visible secondary roots within 4 days of incubation, whereas the seedlings grown in culture filtrates at $10^{-1}$ dilution showed complete absence of the secondary roots.

The percent increase in root development in culture filtrates of isolates 11653 , 11654 , and 11683 did not differ statistically from each other at $10^{-1}$ dilution. However, culture filtrates of these isolates killed 27 to $47 \%$ of the seedlings within 4 days of incubation. The tomato isolate culture filtrate had a strong root growth inhibitory activity compared with the rest of the toxin producing isolates but was not capable of killing any of the seedlings. This was consistent with the lower percentage of the necrotic area of the cotyledons (Table 2) and the mild symptoms produced by this isolate on cotton seedlings. A similar reaction of this tomato isolate was also observed in earlier studies (3).

The toxin-producing isolates 11660 , 11685 , and 11679 did not differ statistically from each other at $10^{-1}$ dilution in the percent increase in root growth, but the percentage of dead seedlings varied among the isolates between 27 and 40. Highest percentage of dead seedlings $(60 \%)$ resulted from infiltration with the culture filtrate of isolate 11687 , which differed statistically from the other three isolates and the control (Table 3). Although a high correlation was found between the percentage of necrotic area of the cotyledons and the percentage of dead seedlings $(r=0.85)$, the latter seems to be a better parameter to classify the isolates according to their toxin production potential.

Most of the culture filtrates lost their activity at a dilution of $10^{-2}$ in the root bioassay (Tables 2 and 3). Culture filtrates
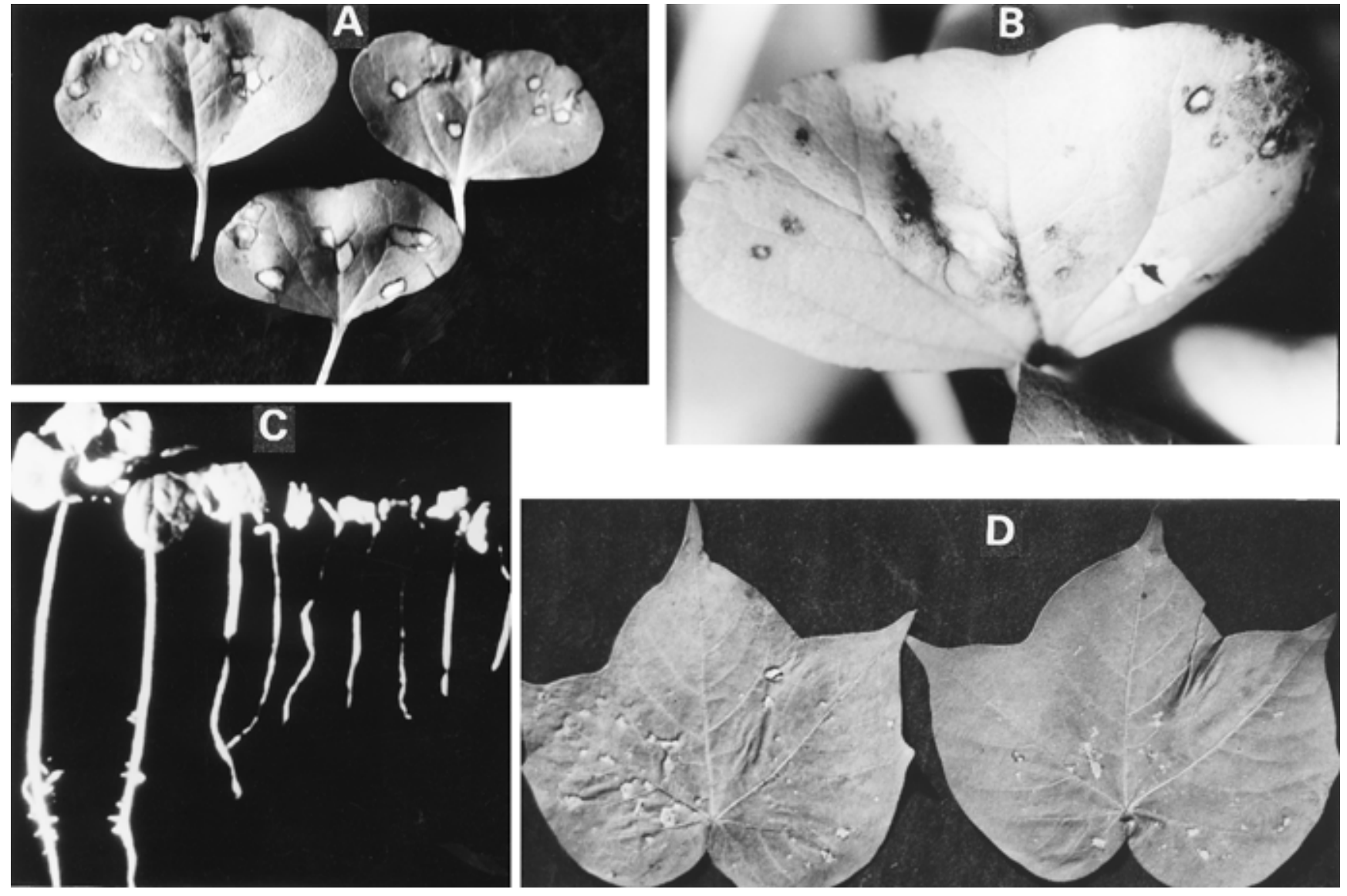

Fig. 1. Symptoms on cotyledons, roots, and true leaves of cotton produced by Stemphylium solani and its autoclaved culture filtrate at $10^{-1}$ dilution, 4 days after inoculation-infiltration: (A) on cotyledons by the culture filtrate; (B) on cotyledon by $S$. solani; (C) on roots by the culture filtrate (two healthy seedlings on left as control); and (D) on true leaves by $S$. solani (left) and by the culture filtrate (right). 
at $10^{-3}$ dilutions were completely inactive. With the exception of isolates 11683 and T1953 , a dilution of $10^{-1}$ was considered as the dilution end point.

Host/cultivar specificity. A high correlation coefficient between the LAI and the LAN of the 38 cotton cultivars was observed when one of the aggressive isolates, 11687, was tested $(r=0.86)$. Cultivars CNPA T-1180-23, CNPA-PRECOCE 2, PR 94 215, and PR 9482 were resistant to the pathogen as well as insensitive or moderately sensitive to its toxin. Cultivars showing intermediate (moderately resis-

Table 4. Relationship between the percentage of leaf area infected by Stemphylium solani (isolate 11687) and the percentage of necrotic leaf area by its autoclaved culture filtrate at 1:10 dilution, of young leaves of adult plants of 38 cotton cultivars, 9 days after inoculationinfiltration

\begin{tabular}{|c|c|c|}
\hline Cotton cultivar & $\begin{array}{l}\text { \% LAI by } \\
\text { S. solani }\end{array}$ & $\begin{array}{c}\text { \% LAN by } \\
\text { culture } \\
\text { filtrate of } \\
\text { S. solaniz }\end{array}$ \\
\hline PR 94-82 & 0 & 0 \\
\hline CNPA T-1180-23 & 0.1 & 0.2 \\
\hline CNPA-PRECOCE- 2 & 0.3 & 2 \\
\hline PR 94-215 & 0.3 & 0 \\
\hline PR 92-126 & 0.8 & 0.1 \\
\hline PR 94-217 & 1.1 & 1.4 \\
\hline CNPA-TB-46 & 1.2 & 0.5 \\
\hline CNPA-TB-93 & 1.3 & 4.7 \\
\hline PR 94-247 & 1.4 & 0.1 \\
\hline PR 94-204 & 1.5 & 0.1 \\
\hline CNPA 87/61 & 1.6 & 1 \\
\hline CNPA PNH-4 & 1.6 & 1.6 \\
\hline PR 94-238 & 1.6 & 0.4 \\
\hline CNPA- & 1.8 & 2.1 \\
\hline \multicolumn{3}{|l|}{ PRECOCE-1 } \\
\hline PR 94-514 & 1.9 & 0.1 \\
\hline PR 94-248 & 2.2 & 0.6 \\
\hline CNPA-TB-38 & 2.5 & 4.8 \\
\hline IAC-20 & 3.3 & 7.1 \\
\hline CNPA $2 \mathrm{H}$ & 3.7 & 6 \\
\hline CNPA 94/145 & 4.4 & 1.4 \\
\hline CNPA 94/109 & 6.6 & 0.3 \\
\hline CNPA-86/1191-1 & 6.6 & 4.2 \\
\hline PR 94-608 & 7.1 & 5 \\
\hline PR 94-09-31 & 7.7 & 7.9 \\
\hline PR 94-50 & 8.7 & 9.1 \\
\hline PR 94-70 & 9.2 & 6.5 \\
\hline PR 94-O9-50 & 9.4 & 11.9 \\
\hline PR 92-122 & 9.6 & 8.5 \\
\hline OC-94550 & 10.8 & 1.6 \\
\hline PR 94-601 & 12.3 & 3.9 \\
\hline CNPA 91/23 & 12.6 & 0.5 \\
\hline CNPA 7H & 12.7 & 3.9 \\
\hline OC-9460 & 18.4 & 4.5 \\
\hline PR 94-127 & 18.7 & 10.1 \\
\hline PR 94-214 & 18.9 & 2.4 \\
\hline PR 94-216 & 19.2 & 16.1 \\
\hline Paraná 3 & 25.3 & 25 \\
\hline PR 93-129 & 49.1 & 36.9 \\
\hline
\end{tabular}

${ }^{\mathrm{z}}$ Leaf area infected (LAI) and necrotic leaf area (LAN) are means of three leaves per cultivar and were measured using automatic area meter, LICOR, model LI-3000, (LAMDA Instruments Corp., Lincoln, NE). Percentage of LAI between 0 and 0.5 was considered resistant, between 0.5 and 5.0 moderately susceptible, and more than 5.0 susceptible. The correlation coefficient $(r)$ between LAI and LAN was 0.86 . tant) reaction to the pathogen also showed an intermediate reaction to the culture filtrate. Similarly, the highly susceptible cultivars Paraná 3, PR 93-129, and PR 94-
216 were also highly sensitive to the culture filtrate (Table 4, Fig. 2).

Of the 18 plant species, seven were considered susceptible to the pathogen $(G$.

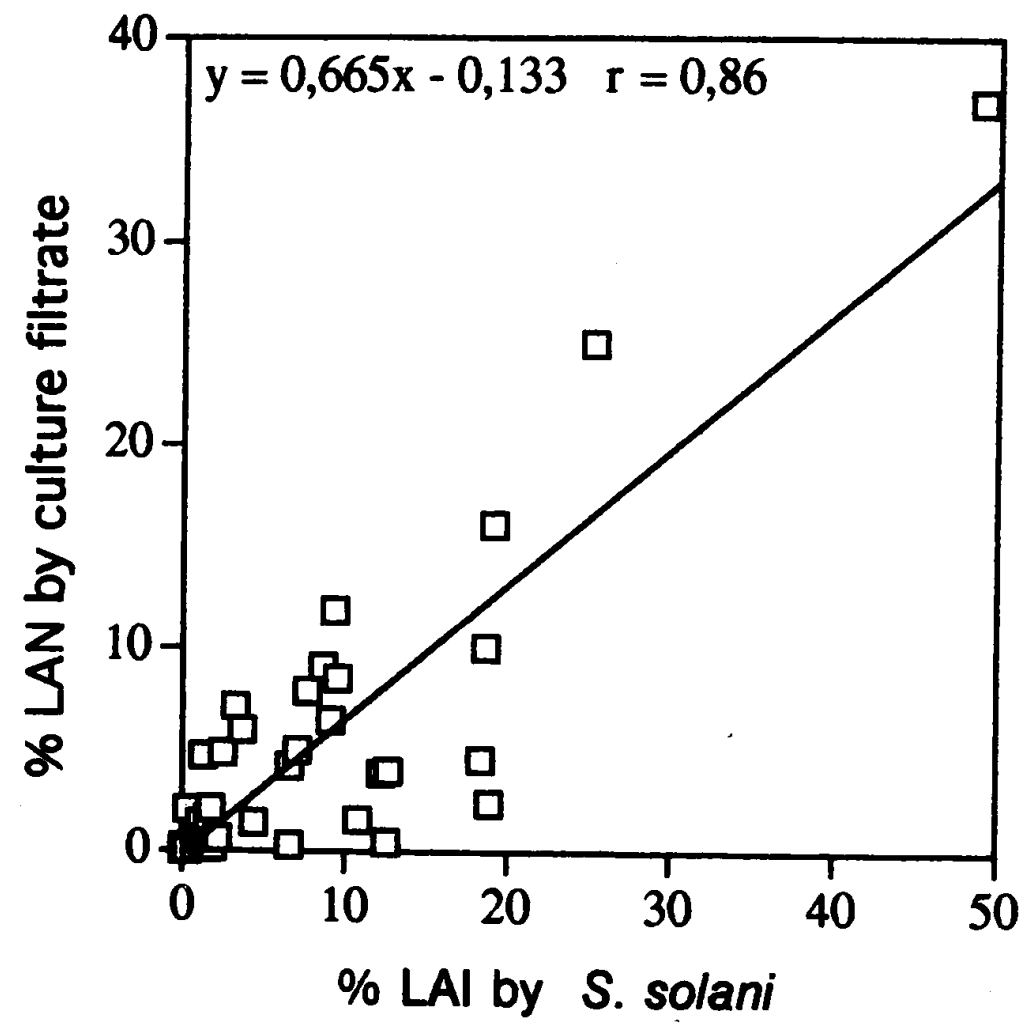

Fig. 2. Relationship between percentage of leaf area infected (LAI) by Stemphylium solani and percentage of necrotic leaf area (LAN) by its culture filtrate of adult plants of 38 cotton cultivars, 9 days after inoculation-infiltration.

Table 5. Relationship between the percentage of leaf area infected (LAI) by Stemphylium solani and the percentage of necrotic leaf area (LAN) by its autoclaved culture filtrate at 1:10 dilution, of young leaves of some host and nonhost species

\begin{tabular}{|c|c|c|c|c|c|}
\hline \multirow[b]{2}{*}{ Crop } & \multirow[b]{2}{*}{ Genus } & \multirow[b]{2}{*}{ Species } & \multirow[b]{2}{*}{ Cultivar } & \multicolumn{2}{|c|}{$\% \mathbf{L A I} / \mathbf{L A N}^{\mathrm{z}}$} \\
\hline & & & & S. solani & Culture filtrate \\
\hline Coffee & Coffea & arabica & Mundo Novo & 0 & 0 \\
\hline Crotalaria & Crotalaria & anageroides & PCD-I 192 & 0 & 0 \\
\hline Crotalaria & Crotalaria & retusa & PCD-I 556 & 0 & 0 \\
\hline Barley & Hordeum & vulgare & BR 2 & 0 & 0 \\
\hline Maize & Zea & mays & XL-321 & 0 & 0 \\
\hline Oats & Avena & sativa & IAC 7 & 0 & 0 \\
\hline Peas & Pisum & sativum & IAPAR-58 & 0 & 0 \\
\hline Rice & Oryza & sativa & Agulhinha & 0 & 0 \\
\hline Rye & Secale & cereale & BR 1 & 0 & 0 \\
\hline Triticale & X. Triticosecale & $X$. Triticosecale & Arapoti & 0 & 0 \\
\hline Wheat & Triticum & aestivum & Mirim & 0 & 0 \\
\hline Mucuna & Styzolobium & atterrimum & PCD-I 201 & 1.2 & 0.8 \\
\hline Crotalaria & Crotalaria & paulinea & PCD-I 187 & 1.6 & 0 \\
\hline Crotalaria & Crotalaria & mucronata & PCD-I 194 & 1.7 & 0 \\
\hline Faba beans & Vicia & $f a b a$ & Palotina & 2.3 & 5.2 \\
\hline Lupines & Lupinus & albus & Floresta & 7.7 & 4 \\
\hline Soybean & Glycine & $\max$ & EMBRAPA 4 & 12 & 5 \\
\hline Crotalaria & Crotalaria & spectabilis & PCD-I 189 & 27.3 & 5.6 \\
\hline Potato & Solanum & tuberosum & Achat & 38 & 18 \\
\hline Tomato & Lycopersicon & esculentum & Agricica & 90 & 5 \\
\hline Cotton & Gossypium & hirsutum & Paraná 3 & 100 & 100 \\
\hline Beans & Phaseolus & vulgaris & Carioca & 100 & 100 \\
\hline
\end{tabular}

${ }^{\mathrm{z}}$ LAI and LAN are means of three leaves per cultivar, measured using automatic area meter, LICOR, model LI-3000 (LAMDA Instruments Corp., Lincoln, NE). The correlation coefficient $(r)$ between LAI and LAN was 0.83. Inoculations-infiltrations were made using a mixture of seven S. solani isolates $(11653,11654,11660,11679,11683,11685,11687)$. 


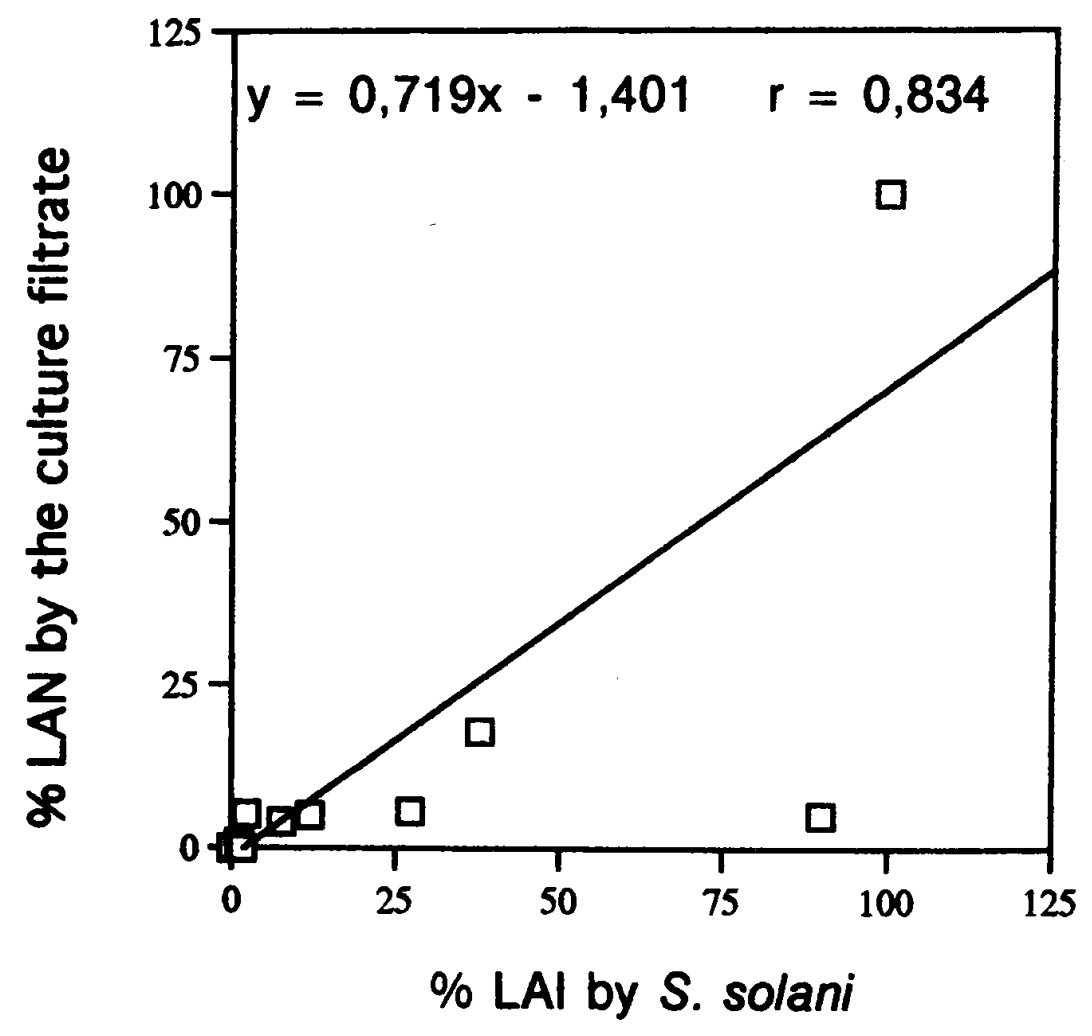

Fig. 3. Relationship between percentage of leaf area infected (LAI) by Stemphylium solani and percentage of necrotic leaf area (LAN) by its culture filtrate of young leaves of some host and nonhost species (See Table 5 for hosts).

hirsutum, Crotalaria spectabilis, Phaseolus vulgaris, Lupinus albus, Solanum tuberosum, Glycine max, and Lycopersicon esculentum). With two exceptions (Crotalaria mucronata, C. paulinea), moderately susceptible hosts also were sensitive to the phytotoxin, whereas nonsusceptible hosts were insensitive to the phytotoxin (Table 5, Fig. 3).

\section{DISCUSSION}

The fact that the phytotoxic component(s) of the culture filtrate was not degraded by autoclaving indicates that it likely is not an enzyme or a protein. Eight pathogenic isolates of $S$. solani tested produced a phytotoxic metabolite(s) in culture, and upon infiltration into leaves of susceptible cotton cultivars mimicked typical Stemphylium leaf blight symptoms. The sensivity of the culture filtrate was associated with the resistance of the cultivar. Similar findings were reported by Kuo et al. (1) for other
$20 \mathrm{~min}$ at $120^{\circ} \mathrm{C}$, the 10 -fold concentration of the toxin under partial vacuum at $45^{\circ} \mathrm{C}$ did not show 10-fold increase in activity compared with the original toxin-containing culture filtrates. The culture filtrate may have contained more than one metabolite, and the concentration process under partial vacuum may have inactivated some of the toxins. Further work is needed to characterize the phytotoxic components of the culture filtrate.

Culture filtrates produced by only eight isolates of $S$. solani were studied, and other isolates may prove to be better toxin producers. Although the effect of different media on the amount of toxin production was not studied, it is possible that higher amounts can be produced using special medium like Frie's medium amended with $0.1 \%$ yeast extract (6). After identification, the toxins may also be useful in tissue culture work to make early selections for resistance to this new cotton pathogen.

\section{ACKNOWLEDGMENTS}

We thank J. Lima for providing some of the laboratory facilities and N. S. Fonseca, Jr. for his help in statistical analysis. Technical assistance was provided by A. Souza.

\section{LITERATURE CITED}

1. Kuo, M. S., Yoder, O. C., and Scheffer, R. P. 1970. Comparative specificity of the toxins of Helminthosporium carbonum and Helminthosporium victoriae. Phytopathology 60:365-368.

2. Lamari, L., Ballance, G. M., Orolaza, N. P., and Kowatsch, R. 1995. In planta production and antibody neutralization of the Ptr necrosis toxin from Pyrenophora tritici-repentis. Phytopathology 85:333-338.

3. Mehta, Y. R. 1998. Severe outbreak of Stemphylium leaf blight, a new disease of cotton in Brazil. Plant Dis. 82:333-336.

4. Olbe, M., Sommarin, M., Gustafsson, M., and Lundborg, T. 1995. Effect of the fungal pathogen Bipolaris sorokiniana toxin prehelminthosporol on barley root plasma membrane vesicles. Plant Pathol. 44:625-635.

5. Pringle, R. B., and Scheffer, R. P. 1963. Purification of the selective toxin of Periconia circinata. Phytopathology 53:785-787.

6. Pringle, R. B., and Scheffer, R. P. 1964. Hostspecific plant toxins. Annu. Rev. Phytopathol. 2:133-156.

7. Pringle, R. B., and Scheffer, R. P. 1967. Isolation of the host-specific toxin and a related substance with nonspecific toxicity from $\mathrm{Hel}$ minthosporium carbonum. Phytopathology 57:1169-1172.

8. Walton, J. D., and Panaccione, D. G. 1993. Host-selective toxins and disease specificity: Perspectives and progress. Annu. Rev. Phytopathol. 31:275-303. 